\title{
Total Quality Management Practices and Performance of Commercial Banks in Kilifi Town, Kenya
}

\author{
Dorotia Wandoe Waduu, Maina Rugami
}

Department of Business Administration, Kenyatta University, Kenya

\begin{abstract}
Any business entity aims at attaining high level of customer satisfaction. The entity always does this by providing quality goods and services. It is crucial that within a firm, all of its internal clients are fulfilled in ensuring that effective satisfaction of external clients is attained. TQM has been presently presented as the means of management that focus in improving an organization's financial performance by attaining customer needs and quality of product provision. The research primary focused on examining the key impacts of TQM on management and financial performance of Kenya's banks in Kilifi Town. The study's objectives were based on establishing the impact of staff involvement, the management commitment, regular improvements and customer focus of the bank's performance. The entire research was based on Deming's theory of TQM and Porter's theory of competitive advantage. In attaining the research objectives, the research utilized descriptive research technique and a population of 195 participants from 13 commercial banks in operation within the Town of Kilifi. A 30 percent sample was considered reflections of 59 participants. In getting information from the respondents the study utilized both structures and unstructured questionnaires that consisted of both open and closed ended questions. However, respondents had varying questions and had the opportunity to answer appropriately. SPSS (Version 22) stands out as one of the key analysis tool to be used in examine the quantitative data collected, and then the information was presented by the use of means, frequencies, percentages, standard deviations an means. The research utilized multiple regressions analysis in estimating the study model. The study's gathered and analyzed data was presented by the use of tables, charts, graphs and frequencies meant to enhance the process of interoperations, provision of conclusions and recommendations. Theoretically, the research is expected to be of importance both to firms expected to use the information in enhancing quality products provisions and academicians expected to do researches on a similar or related topic. It was established that the selected TQM practices which included customer focus, top management commitment, continuous improvement and employee involvement significantly and positively influence the performance of commercial banks in Kilifi Town. The study concluded that the banks to a great extent embrace the four $T Q M$ practices in a bid to improve service provision, client attraction and retention and also improve organizational performance. It was further concluded that the banks embrace continuous process, procedures and system improvement to enhance operational efficiency and customer satisfaction. The study also concluded that the banks valued customers in a bid to enhance market share and customer base and also stay competitive in the market. The study further concluded that the top management was committed to enhancing service quality, employee participation and involvement in quality integration, stakeholder involvement, communication and collective decision making. The study recommends that the banks need to involve employees and stakeholder more in decision making and policy formulation to promote collective responsibility and performance. The study recommends that there is need for improved customer care to cater for all categories of clients and also embrace value addition to the clients. The study was conducted on only four TQM practices, there is need for further studies on other TQM practices.
\end{abstract}


Key Words: Total Quality Management, Employee Contribution, Top Management Commitment, Continuous Improvement, Customer Focus, Performance of Commercial Banks

DOI: 10.35942/10.35942/ijcab.v3iVI.75

\section{Cite this Article:}

Waduu, D., \& Rugami, M. (2019). Total Quality Management Practices and Performance of Commercial Banks in Kilifi Town, Kenya. International Journal of Current Aspects, 3(VI), 1-15. https://doi.org/10.35942/ijcab.v3iVI.75

\section{Introduction}

The banking industry has currently been embraced having developed as back from 1980 where industry would provide products of different quality. An organization always strategized towards providing quality services to its clients that fulfill their needs, then the entity definitely is attaining and observing Total Quality. The general practices of Total Quality provision demands for quality service in the entire firm's dimensions and the company must fully be involved and allocate effective resource towards the development of quality services (Stock and Mulki, 2009).Most organization has been forced to embrace the spirit of innovation and completion due to the increasing rate of globalizations with the objectivity of meeting international quality standards. Besides, to effectively attain the globally competitive edge, organizations have been forced to continually enhance their quality provisions by embracing product differentiations, marketing and cost reducing strategy (Changand Huang, 2015). The banking industry has globally effectively expressed a great performance ad also enhanced their performance regardless of their increasing rate of competition. Total Quality Management has been introduced into the space due to the rising rate of competition. Most of the commercial banking institutions have managed to be sustainable as their assets of shareholders and deposit grew by 32.9 and 35.35percent respectively (Central Bank of Kenya, 2010). The institutions have utilized different management styles with the objective of attaining their goals and targets

Performance mainly expresses the attainment of financial gain. An entity's performance is determined by its ability to make profits be it economic or accounting. An entity's performance rate is determined through its profitability levels. The measurement unit is basically a fundamental goal of nay business venture without which an entity may not have a long term competitive edge. A firm's profitability is mainly measured through incomes and expenses, as incomes reflects on the amount of money attained from the entity's activities for instance interest income gained from banks and expenses being cost incurred from the entity's activities. The entity's profitability levels are determined through the firm's income statement. Hence is any organizational performance profitability is key and manager's role largely focuses on enhancing the structural form of increasing the firm's profitability level. As a way of increasing the entity's profitability level, various systems have to be adopted with TQM being one of the currently competitive supporting systems that aims at enhancing the firm's profitability rate and reducing its loan defaulter losses. Researchers have been done on the determinants of bank's profitability and on its ROA and ROE and its net interest rate margins have been identified as key determinates. According to Kuntet al (2011), a bank's performance and its interest margins have been reflected as key indicators of the institution's inefficiency and efficiency in the banking systems as the two play a key role of driving a wedge between the rate of interest being obtained by the savers on their deposit as well as the interest attained from borrowers. As narrate by Rasiah (2010), profitability measure is valued as key for stockholders of the institutions as it reveals that rate of earning nature on their investments. Rasiah (2010) also provides out that, there exist two types of interest that affect 
a bank's profitability rate and this include interest income and interest expenses. The two categories of interest affect an institution's net interest income a factor that directly affects the profitability rate (Bennaceur et al. (2013).

TQM reflects on the technique by which an organization and its staffs get engaged in continuous improvement of the productions of products and services. According to Hashmi (2010), the systems reflect on combinations of TQM tools focused on enhancing entities and lowering losses resulting from wasteful activities. Basically TQM is definite description of an organization's culture, attitude as well as the engagement of staffs in providing clients with goods and services that fulfill the requirements. The culture needs quality at all levels of the organization's functions, with procedures being conducted effectively on first period and eradicating any arising faults or wastes from its operations (petres, 2014). TQM philosophy starts from top, i.e. from the organization's executives to the line employees. TQM fundamentally focuses on the fulfillment of client's needs. The systems needs that the firms establishes customer focused operational processes and largely allocate enough resources meant to attain customer satisfaction. Basically the system requires both dedication from the managerial body and an effective transition of organizational culture that embraces the system. On the other hand, TQM leaders view an organization as system which empowers staffs and develops a multipoint communication amid the firm's staffs and clients as well as application of information effectively. TQM needs an efficient knowledge management to effectively certify that staffs attain timely, accurate, and information as they require to accomplish their responsibilities more effective an efficiently within the organization. The model is focused with the continuous improvement in an organization's design and operations processes, starting from planning levels to the decision making and executions phases by the frontline staff.

The Kenyan industry is grouped into three tiers totaling to43 banking houses. The grouping consists of both the public and commercial institutions though there exists no public banks an all always focus on making and improving their profit rates. The Central Bank of Kenya recognizes the presence of 43 bankswith6 banks grouped at the top tier with the capacity of controlling around 50\% of the country'smarket.Tier2as well contains 16 banks grouped to controlalmost 42 percent as the third tire made of 21 small private banks control the remaining market. Key top tier banks as recognized by CBK are Equity Bank, CBA, Cooperative, Standard Charted, and Barclays. The second tier contains Eco Banks, Family Bank, CFCStanbic, Diamond Trust and I\&M. The third tier contains other small private banks such as JamiiBora, Guardian and Baroda.

\section{Statement of the Problem}

The banking sector for years has been characterized by insistent operational ineffective customer services and to efficiently discourse the issues most of the firms are highly embracing Total quality Management with the objective of making them efficient in attaining their customer's needs (Maxwell, 2011). As much as TQM activities have been identified by most firms' strategy of changing the organization's management practices and its ability to transform its financial results there have rose issues on the legitimacy of quality management activities in enhancing financial performance of organizations. Besides, other researchers have been recognized as from1980'swith the objective of exploring then difference amid TQM practices and financial progression. According to Ugboro (2011)'s study on the utilizations of TQM, in spite that quality management has been adopted in most firms, TQM's underlying assumptions are applicable to strategy management. Though the research would express that the utilizations of TQM within the IT sector, results that may be ineffective in the banking field. Based on Mwangi's (2013) study, he expressed that 
stakeholders such as NGO's are highly focusing on education but doesn't indicate what further fields are to be concentrated on for performance enhancement. According to Moghimi and Anvari's (2014) survey evaluating the link between TQM on 40 Iranian cement organizations. From a sample of 25 firms, utilizing qualitative and quantitative data and descriptive statistics technique. According to the findings there exists an effective link between an organization's performance and TQM in Iran's cement firm (Rono (2013). In Kenya various efforts have been identified and applied to enhance the quality of the commercial institutions, this is focused on attaining quality services to attain the increasing needs of clients. In spite of measures provided to ensure executions of TQM some institutions have had issues limiting their development (Ogada, 2012). The research thus aimed at filling this gap by developing the link between TQM practices and the performance of Kilifi Town's Commercial Banks.

\section{Objectives of the Study}

The study's objective focused on investigating the effect of TQM on the performance of commercial banks in Kilifi Town.

The specific objectives included;

i. To investigate the effect of employee contribution on performance of Kilifi Town's commercial banks.

ii. To explore the effect of top management commitment on performance of Kilifi Town's commercial banks

iii. To ascertain the effect of continuous improvement on performance of Kilifi Town's banks.

iv. To investigate the relationship between the customer focus and the performance of commercial banks in Kilifi Town.

\section{Theoretical Review}

This chapter's part provides relevant approaches that are to reviews in relations to the researcher's objective. The research was grounded on various theories which the researcher deems relevant and crucial to the study's objectives and goals.

\subsection{Resource based view theory}

This is theory that provides that internal resources of a firms are inimitable, scare and without a substitute hence making them part of the sustainable competitive edge (Penrose, 1959) thus contributing much to the firm's performance (Hockman\& Grenville, 2004). The theory provides out that a firms' performance is largely enhanced by its available resources, while the source of the higher performance as entrenched in the ownership and distribution of distinct resources which are hard to duplicate (Werner felt, 1984). The model as well provides that organizations attain justifiable competitive advantage in case they retain specific key resources and in case they efficiently position the resources in their selected marketplaces (Barney, 2007) On the other hand, O'cases another Fellow scholars (2004) argues that an organization's certain features have the ability to produce central resources which are hard to duplicate and greatly define the performance discrepancy amongst the rivals. The model as well illustrates out that its market competitiveness and higher financial performance greatly relies on its product and services quality, capabilities as well as on its resources (Fotopoulos, Kafctzopoulos \& Psomas, 2009).

As stated by Barney (2001) an organization establishes a competitive edge by not only obtaining but also through growing and efficient allocating its resources more effectively in 
comparison to its c competitors. The theory hypothesizes that competitiveness is attained from the organization's internal resources (Werner felt, 1984). Wernerfelt,1984; Orlando (2000) provides that the model applies the assumption providing that an organization is a package of resources. Its assets consist of all of its intangible and tangible assets that enable it to consider develop and execute approaches that enhance its effectiveness and efficiency. The firm's tangible assets include all physical materials that it has this include resources like, raw materials, tool and equipment's and facilities (Daft, 1983, Johnson, et al, 2004). The firms intangible assets include resources unseen but contain the firm's value ad can be used as part of the competitive edge such as brand name, networks. All these resources offer value to the firm's performance.

Besides, Barney (2007) also provides that for a firm to transform its short-term competitiveness to a more sustained viable completion it needs more mobile and heteronomous resources. Barney would further point out that in case conditions are held constant, the organization's resources can and sustain above average returns. The model is crucial to the research because TQM practices are a resource of establishing quality picture that a firm can utilize in enhancing its performance. TQM activities need to be scare, valuable and inimitable and non-sustainable for the manufacturing organization to attain the expected competitive advantage a factor that contributes to its enhanced performance. Fundamentally there exists connection between environment and economic performance of an organization a factor that yields multiple competitive advantages (Klassen \& Whybark (1999).For instance, an organization may establish constant development tin place to attain universal accreditation for quality. According to Hart (1995), such a strategy resource can be effectively be transferred and utilized in the execution of protective technologies, offering a theoretic ground for incorporated methods like total quality environment management (Willing , 1994). Makadok (2001) illustrates out that RBV basically emerged between capabilities and resources, as capability of non-observable and intangible as resource is observable asset (Karthi et al, 2012).

As narrated by Makadok (2001), capability and resources have two disguising features, for instance capability is an organization-certain as it is entrenched in the firm and its operations a and two the fundamental determination of capability is to improve an organization's productivity of all of the firm's resources considering that a firm's resources express abundant agreement of the structures of competences. DiMaggio \& Powell (1991) provides that, in discrepancy, crucially RBV model is considered as inimitable, rate, non-substitutable resources that establish an organization's heterogeneity and that more effective organizations are organizations that reserve valued which leads to firm's effective performance. Organizational preparedness defines the nature of quality management systems to offer, this is considering out that an organizations resources influences is performance. The undertaken strategies are meant to influence the performance of an organization and help in attain a competitive edge in the market, a factor that results to enhanced performance. Thus the theory supports variables of the commitment of a firm's management, and continuous improvement.

\subsection{Deming's Theory of total quality management}

The model is fundamentally based on fourteen management points, reflective knowledge systems and primary focusing on Shewart Cycle. Deming has been prominent on his ratio that provides out that quality is as a result of work efforts over total costs. In case affirm focused on costs, a challenge is expected to arise while the quality levels deteriorate. He profound knowledge systems comprises of: understanding how an organization's process operate, the occurrence of variations and the reason of the variation occurrences. The model 
focuses on the development of purpose of reliability, its establishing new philosophy adoption, values the dependence on mass inspections and disapproves the awarding business courtesy of price. The theory as well points out that there exists a continuous and enhanced provision of services, performance grounded on enhanced job training, infusion of quality, eliminate departmental hindrances; eliminating work goals mainly focused on quality achieved and highly embrace and support pride in craftsmanship, enhanced training and encourage educational processes within the organization and ensure that the firm's executives facilitates the key points.

\subsection{Porter's Theory of Competitive Advantage}

The theory largely Pioneered by Porter (1980), provides the competitive forces model that views the importance of competitive strategy formulation as one of the factor that relates an organization to its surroundings. The model provides that, one of the major key aspects of its environment is the industry in which it competes. An industry's framework tends to impact the nature of competitiveness. Under the competitive forces model, five industry level forces entry barriers, bargain power for suppliers, buyers, threat of substitutions and rivalry amid industry influences the inherent profit potential of an organizations. The model can be applied in helping an organization have a strong competitive edge. The model's five force structure offers a systematic manner of examining how competitive forces operate in an organization and the manner in which the forces help in determining the profitability of various industries and the industry segment. An organization's competitive forces structure as well comprises of various assumptions on the sources of competition and the nature of the strategy process. Available competitive strategies as expressed by Porter (1980) are always focused at changing an organization's position within its industry. An industry's framework plays a major role in examining and restricting strategic plans. Various industries or subsectors have nee attractive basically because they contain structural impediments of establishing a sustainable competitive advantages. For instance as stated by Teece, (1984), organizational rents are being developed at the subsector level rather than at the firm level. As much as there exists some recognition provided to organizations, certain assets, differences amid organizations relate fundamentally to scale. Thus the model provides that TQM practices form part of the pivotal pillars in enhancing an organization's operational performance.

\section{Empirical Review}

The section provides various previous empirical evidence, focusing on employee engagement, technology embracement, continual improvement and clients focus on the progression and the performance of Kilifi's Commercial Banks. TQM efficiency in an organization is enhanced by first encouraging employees to be engaged in TQM execution. Other than involvement, the organizations should as well empower the staffs by involving them in decision making process and the end results of this is by the organizations gaining from its continual improvement of its businesses and systems. Usually employee contains key innovative ideas that can be of great help to the organization's performance. Their involvement, improves their productivity level as this results to high motivation to effectively and comfortably work with each other (Besterfield, Michina \& Sacre, (2010).Staffs always engaged in an organization's TQM practices as group positivity, effect on the organization quality drive as stated by Annibal and Bilich (2010). However, an organizations requires a formalize systems of celebrating, monitoring and motivating its staff under the quality management systems. Inefficiency to effectively engage the staff tends to lower their productivity level. An organization's management requires establishing an environment which embraces staffs to be engaged in the organization's quality practices. The 
environment's objectivity will be, developing a positive attitude amid the staffs, a factors value to enhanced motivation and general productivity (Mann, 2009).

A firm's financial performance is highly dependent on the commitment of the executives, and the employees (Powell, 1995).The company's top management plays a key role in maintaining the required leadership for quality management systems, with the engagement of all of the firm's staffs. The key responsibility coordinated by the top management includes ensuring that there are available resources to the employees to ensure that services are improved, the top management also helps in creating and appraising the firm's quality strategy and goals quarterly to certify adherence to the principles of quality (MacDonell , Soltani, 2015), Mcleod and (2011) focused on the significance of a firm's executive in an organizations, he expresses that top management empowers user participations, provides a positive context of cultural change, helps in managing political and social conflicts, and influences the working attitudes and ensuring that there are enough facilities and resources.

Cole and Phili (2011) defines leadership being the procedure of empowering others in understanding and agreeing on the needs to be done, the manner they a rot be one and the process of affiliating individual and various mutual efforts to united goals. The leaders are responsible of providing definite visions of the firm's future and set challenging objectives. It's basically by unity of purpose and direction of staffs that attains firm's goals. The leaders should maintain its internal environment where the firm's staffs can be engaged by developing trust and eliminating fear. The leaders by the key role of defining the firm's vision, mission and goals that expect to promote the firm's quality culture and develop supportive shared values that enhance the firm's performance (Kanji, 2013).Thus, the top management requires fully involvement towards attaining the company's key mission, visions and objectives (Terziovskiet, al., 2013). The degree of a positive business project highly relies on the extent of the project's top management commitment. Three major facts of managerial support that are important in TQM practice involves; expressing interest through the involvement of teams, engaging with employees are receiving feedbacks and provide effective fee backs, resolve issue s, provide training and key leadership standards. The fact that an organization's top management is assumed to establish the general guidelines of the business entity by formally establishing an active executive to attract, review and help in monitoring the project's activities and progress ( Olorunniwo \& Udo, 2012).

An organization's improvement may include multiple objectives producing products with non-effects or attaining $100 \%$ customer fulfillment however regular and continuous improvement offers similar fundamental philosophies regardless of the expected objectives and goals (Murphy and Elana, 2006). The basic values consist: engagement with the firm at all departs an levels, find saving by enhancing the current systems, reducing the level of money investment, collecting data on the firm's operations quantifying that data, that is considered fundamental against which the firm's improvements are to be determined/measured on the basis of continuous improvement (Morgan , 2006). Continuous improvement always comprises of developing a structure that includes all of the firm's departmental representatives. The structure consisting of a team of members from the departmental levels plays the role of understanding the firm, then appropriate quantitative information is developed (Mcmanus, 2009). The group provides key resolutions on the firm's management and starts executing the solutions. Once that is attained, follow ups mechanisms should being lacemeant to seek additional improvements as times goes by. As solutions are continuously implemented, any possible changes can be made with the objective of meaning both the firm's and customer's goals and needs respectively (Kinni and Theodore, 2015).According to Joiner and Brian (2017), the systems will greatly enhance employee involvement a concept that will in turn enhance continuous improvement. 
As stated by Mitchell (20130,market innovation involves the enhancement of market mix and the way in which the needs under the market are fulfilled with the objective to improve the market potential and enhance different strategies of serving within the target markets. Key market leaders with the skills are fast to identify the unique features of clients like their buying trends and will as a result develop their preferences. To effectively fulfill the customer's new preferences, then company must always segment the clients and differentiate their products with the objectivity of satisfying them. For a business entity to attain features meant to offer them a competitive edge there is needs to research for attitudes and behaviors of customers a factor that further meant to derive continuous and effective performance (Narver and Slater).According to Hult and Fellow Scholars (2004), converting marketing knowledge into practices in decision making process and planning is expected to follow automatically (Narver,et al. 2011) .

\section{Conceptual Framework}

Independent Variables

Dependent Variable

\section{Total Quality Management}

\section{Employee involvement}

- Knowledge sharing

- Employee satisfaction

\section{Customer focus}

- Knowledge management

- Quality of products

Continuous improvement

- Trainings

- Audit results

\section{Top Management} Commitment

- Quality Objectives

- Quality Policies

\section{Performance of Banks}

- Customer Satisfaction

- Customer Retention

- Profit margin

\section{Figure 1: Conceptual framework}

Source: Author (2017)

Conceptual structure is reflections of fundamental arrangement which comprises of specific abstract blocks that denote the observational, experimental and synthetically aspects of systems that are being embraced. A study's conceptual framework reflects one set of ideas as well as standards gathered from appropriate fields of enquiry and utilized in structuring 
subsequent presentations. The link between the dependent and independent variables attains the framework for specific anticipated outcomes.

\section{Research Methodology}

The study utilized descriptive technique, the technique aims to express and elaborate a subject by developing a problematic profile, events by gathering information and executing their frequencies. The research is focused at collecting data from the participants on their views based on the impact of Total Quality Management on strategic performance of banks. The target population of the study consisted of 195 staff among the Commercial banks in Kilifi Town. The unit of observation was the 13 commercial banks with branches in Kilifi Town while the unit of analysis was the 195 employees among the banks. The population is effectively valued since they are considered as the key parties that execute and improve TQM practices. A sample of 30 percent provides a good target populations (Mugenda and Mugenda (2013), thus the research had a sample population of 59 reflecting the30 percent using stratified random samples. The study utilized primary data. The data was gathered from participants by the use of both closed and open ended questionnaires. This study applied drop and pick techniques as the participants will receive similar questions. Both descriptive, correlation and was used as well as the inclusion of SPSS 21.0 and regression statistics. Multiple regression statistics was utilized in developing the relationship between TQM practices and performance among Kilifi Town's banks Based on the regression model.

\section{Data Analysis}

The study conducted inferential statistics to establish the effect of total quality management practices on the performance of commercial banks in Kilifi Town. The findings of Model Summary, ANOVA and Regression Coefficients are indicated in subsequent sections below.

The findings of coefficient of determination and coefficient of adjusted determination are as shown in Table 1.

Table 1: Model Summary

\begin{tabular}{lllll}
\hline Model & R & R Square & Adjusted R Square & Std. Error of the Estimate \\
\hline 1 & $.864^{\mathrm{a}}$ & .805 & .844 & 1.71033 \\
\hline
\end{tabular}

Source: Field data, 2019

The findings found out that coefficient of correlation $\mathrm{R}$ was $0.864 \mathrm{an}$ indication of strong positive correlation between the variables. Coefficient of adjusted determination $\mathrm{R}^{2}$ was 0.844 which changes to $84.4 \%$ an indication of changes of dependent variable can be explained by the independent variables which included employee contribution, top management commitment, continuous improvement and customer focus. The residual of $15.6 \%$ can be explained by other factors affecting performance of the commercial banks.

The study carried out an ANOVA at $95 \%$ level of significance. The findings of $\mathrm{F}$ Calculated and $\mathrm{F}_{\text {Critical }}$ are as shown in Table 2.

Table 2: ANOVA

\begin{tabular}{llllll}
\hline Model & Sum of Squares & df & Mean Square & F & Sig. \\
\hline Regression & 841.542 & 9 & 93.5047 & 14.6815 & $.000^{\mathrm{b}}$ \\
Residual & 261.125 & 41 & 6.3689 & & \\
Total & 1102.667 & 50 & & & \\
\hline
\end{tabular}

Source: Field data, 2019 
The findings show that $\mathrm{F}$ Calculated was 14.6815 and $\mathrm{F}$ Critical was 5.6791, this show that $\mathrm{F}$ Calculated $>F_{\text {Critical }}$ an indication that the overall regression mode was significant for the study. The $p$ value was $0.000<0.05$ an indication that at least one variable significantly influenced performance of the commercial banks in Kilifi Town.

The study used coefficient of regression to establish the individual influence of the variables to performance. The findings are indicated in Table 3.

Table 3: Coefficients of Regression

\begin{tabular}{llllll}
\hline & \multicolumn{2}{l}{$\begin{array}{l}\text { Unstandardized } \\
\text { Coefficients }\end{array}$} & \multicolumn{2}{l}{$\begin{array}{l}\text { Standardized } \\
\text { Coefficients }\end{array}$} & \\
\cline { 2 - 5 } Model & $\mathbf{B}$ & Std. Error & Beta & T & Sig. \\
\hline (Constant) & 5.526 & 0.612 & & 2.664 & .000 \\
Customer focus & 0.811 & .132 & .033 & 8.314 & .000 \\
Top management commitment & 0.863 & .142 & .020 & 9.155 & .000 \\
Continuous improvement & 0.769 & .103 & .042 & 9.414 & .000 \\
Employee involvement & 0.841 & .128 & .058 & 10.378 & .000 \\
\hline
\end{tabular}

The resultant equation was

$Y=5.526+0.811 X_{1}+0.863 X_{2}+0.769 X_{3}+0.841 X_{4}$

Where: $\mathrm{X}_{1}=$ Customer focus, $\mathrm{X}_{2}=$ Top management commitment, $\mathrm{X}_{3}=$ Continuous improvement, $\mathrm{X}_{4}=$ Employee involvement. The study found out that by holding all the variables constant, performance of the banks will be at 5.526. A unit increase in customer focus when holding all the other variables constant, bank performance would be at 0.811 . A unit increase in top management commitment while holding other factors constant, bank performance would be at 0.863. A unit increase in continuous improvement for both operational processes and procedures while holding other factors constant, bank performance would be at 0.769 . A unit increase in employee involvement while other factors are held constant, firm performance would be at 0.841 . The findings pointed out that employee contribution, top management commitment, continuous improvement and customer focus had a $\mathrm{p}$ value of $0.000<0.05$ an indication that the selected total quality management practices significantly influenced performance of the banks in Kilifi Town. This is supported by Mwangi (2013) who indicated that adoption of TQM management model of a firm promotes quality services, engagement of all employees and focuses on long term success. All of the firm's achievements can be attained through client fulfillment and benefits to all of the firm's members as well as to the community.

\section{Conclusions}

It was concluded that the selected TQM practices which included customer focus, top management commitment, continuous improvement and employee involvement significantly and positively influence the performance of commercial banks in Kilifi Town. The study concluded that the banks to a great extent embrace the four TQM practices in a bid to improve service provision, client attraction and retention and also improve organizational performance. It was further concluded that the banks embrace continuous process, procedures and system improvement to enhance operational efficiency and customer satisfaction. The study also concluded that the banks valued customers in a bid to enhance market share and customer base and also stay competitive in the market. The study further concluded that the top management was committed to enhancing service quality, employee participation and involvement in quality integration, stakeholder involvement, communication and collective decision making. 


\section{Recommendations}

The study recommends that the banks need to involve employees and stakeholder more in decision making and policy formulation to promote collective responsibility and performance. The study recommends that there is need for improved customer care to cater for all categories of clients and also embrace value addition to the clients. The study recommends further that the firms need to invest in capacity development and modern technology to promote efficiency.

\section{References}

Allen, R. S. and Kilmann, R. H. (2011). The role of the reward system for a total quality management based strategy. Journal of Organizational Change 14(2): 110-131

Amar, K. and Z.M. Zain (2012). Barriers to Implementing TQM in Indonesian Manufacturing Organizations, The TQM Magazine, 14(6), 367-372.

Arumugam, V., Ooi, K. B. and Fong, T. C., (2013). TQM practices and quality management performance- an investigation of their relationship using data from ISO 9001:2010 firms in Malaysia. The TQM Magazine, 20(6), 636-650.

Aryee, S., \& Chen, Z. X. (2006). Leader-member exchange in a Chinese context: Antecedents, the mediating role of psychological empowerment and outcomes. Journal of Business Research, 59(7), 793-801.

Augustyn, M.M., (1998). The road to quality enhancement in tourism: International Journal of Contemporary Hospitality Management, vol 10, p. 1- 5

Barney, J. B. (2011). Firm Resources and Sustained Competitive Advantage. Journal of Management, Vol.17 ,pp 99-120.

Barney, J. B., (2017). 'Is the resource-based 'view' a useful perspective for strategic management research? Yes', Academy of Management Review, 26, 102-105.

Beckmann (2013), "The Power of CLV: Managing Customer

Benner, M.J., and M.L. Tushman (2013). Exploitation, Exploration, and Process Management: The Productivity Dilemma Revisited, Academy of Management Review, 28(2), pp.238-256.

Bergman, B., 1995. "Quality in academic leadership: a contribution to the discussion", Total Quality Management, Vol. 6 No. 5 \& 6, pp. 487-96.

Bowen Rondah (2013) Theories in Total Quality Management. Retrieved on 28, January, 2017 from Slideshare website: http://www.slideshare.net/mendezmeaganrose/theories-in-total-quality-management

Bruton, G. D., Keels, J. K., \&Scrifres, E. L. (2012). Corporate restructuring and performance: An agency perspective on the complete buyout cycle. Journal of Business Research, $55,709-72$

Bureau VeritasSverige.(2017). FSSC 22010Certifiering. [online]. Available from:http://www.bureauveritas.se

Chin, S. K. \& Choi, W. T. (2013). Construction in Hong Kong: success factors for ISO 9000 implementation. Journal of Construction Engineering and Management, Vol. 129 No. 6, pp.599-609

Chrisman, J. J., Chua, J. H., \&Litz, R. A. (2004). Comparing the agency costs of family and non- family firms: Conceptual issues and exploratory evidence. Entrepreneurship Theory and Practice, 28(4), 335-354.

Cooper, D. R., \& Schindler, P. S. (2006). Business Research Methods (9th edition). USA: McGraw-Hill.

Crosby, P. B. (2012). Quality Is Free: The Art of Making Quality Certain. New American Library, New York. 
Cua, K.O., McKone, K.E., Schroeder, R.G. (2011). "Relationships between implementation of TQM, JIT,and TPM and manufacturing performance", Journal of Operations Management, Vol. 19 pp.675-94.

Eisenhardt, K. M. (1989). Agency theory: An assessment and review. Academy of Management Review, 14(1), 57-74.

Evans, J. R., Lindsay, W. M., 2013. Managing for Quality and Performance Excellence. Mason, Ohio: Thomson Business and Economics.

Ezugwu, B.C \&Agu O.A (2016). The Effect of Total Quality Management On Performance In Public Enterprise, International Journal of Advanced Research in Management and Social Sciences, ISSN: 2278-6236

Feng, M., Terziovski, M. and Samson, D. (2013).'Relationship of ISO 9001: 2010 quality system certification with operational and business performance', Journal of Manufacturing Technology Management, Vol. 19, No. 1, pp. 22-37.

Fotopoulus, C.B. and Posmas, E. L (2009). - The impact of soft \& hard TQM elements on quality management results, International Journal of Quality and Reliability Management, Vol 26, no 2, pp 150-163.

Freeman, R.E. (1984). Strategic Management - A Stakeholder Approach, Pitman, Boston, MA

Galbreath, J.(2012). Success in the relationship age: building quality relationship assets ,The TQM Magazine, 2012, Vol. 14, No 1, p. 10.

Gass, G (1997). Stakeholders, science and decision making for poverty focused rural mechanization research and development ,World development, 1997, No 25(1), p.115126

Gitlow. S. Howard. (2010). Quality Management Systems: A practical Guide; 1st Edition. CRC Press.

Goetsch, D. L. \& Davis, S. B. (2013), Quality Management for Organizational Excellence: Introduction to Total Quality. [7th Ed.], NJ: Pearson,

Goldberg, J.S., Cole, B.R. (2012), Quality management in education: building excellence and equity in student performance", Quality Management Journal, 9(4), 8-22.

Government of Kenya (2015).Sensitization Training Manual on Performance Contracting in Public Service: Performance contract steering committee, Kenya Government Printers

Grant, R.M. (2012). Contemporary Strategy Analysis, 4th ed., Oxford: Blackwell

Grönroos, C. (2011) Service management and marketing: a customer relationship management approach. England: John Wiley and sons limited. 2nd edition.

Hancer, M., \& George, R. T. (2013).Psychological empowerment of non-supervisory employees working in full-service restaurants.International Journal of Hospitality Management, 22(1), 3-16.

Hartline, Michael D. Maxham, J G. III; McKee, D. O. (2010). Corridors of Influence in the Dissemination of Customer-Oriented Strategy to Customer Contact Service Employees, Journal of Marketing, 64 (April 2010), 35-50.

Hasan, M. and Kerr, R.M. (2013).The relationship between TQM practices and organizational performance in service organization.The TQM Magazine, 15(4), 286291.

Hendricks, K.B. and Singhal, V.R. (1997) Does implementing an effective TQM program actually improve operating performance? Empirical evidence from firms that have won quality awards.Management Science, 43 (9), 1258-1274

Homburg, C. (1998): "On Closeness to the Customer in Industrial Markets", Journal of Business-to-Business Marketing, 4 (4), 35-72. 
Ittner, C.D. and Larcker, D. (2016) Measuring the impact of quality initiatives on firm financial performance. Advances in the Management of Organisational Quality, 1, 137.

James R. Evans and William M. Lindsay, (2013), The Management and Control of Quality, [7th Ed.], Thomson: South-Western Publisher.

Jinhui Wu, Sarah, Dongli Zhang, and Roger G. Schroeder. "Customization of quality practices: The impact of quality culture. International Journal of Quality and Reliability Management, 2011: 263-279.

Joaquin, D., Hernandez, D., Aspinwall, E., (2010). A framework for building quality into construction projects - part II. Total Quality Management 21 (7), 725-736.

Juran, J. (2009). Juran's Quality Handbook. [6th Ed.] New York. USA: McGraw Hill Publications,

Kanji, G. K. (2013) Measurement of business excellence, Total Quality Management, 9(7), $633-643$.

Kaynak, H. (2013). The Relationship between Total Quality Management Practices and Their Effects on Firm Performance".Journal of Operations Management, 21(4), 405-435.

Kenya Bureau of Standards.(2013). Implementation of ISO 9000 standards handbook. Nairobi, Kenya: Training and Advisory Services, KEBS.

Kolltveit, BjørnJohs, Grønhaug, Kjell (2004). The importance of the early phase: the case of construction and building projects. International Journal of Project Management. Elsevier 22, 545-551

Leonard, D. and McAdam, R. (2004) Total quality management in strategy and operations: Dynamic grounded models. Journal of Manufacturing Technology Management, 15 (3), pp. 254-266

Li, Tiger; Calantone, Roger J. (1998). The Impact of Market Knowledge Competence on New Product Advantage: Conceptualization and Empirical Examination, Journal of Marketing, 62 (), 13-29

Matsuno, Ken; Mentzer, John T. (2010): “The Effects of Strategy Type on the Market

McLeod, L., \&MacDonell, S. G. (2011). Factors that affect software systems development project outcomes. ACM Computing Surveys, 43(4), 1-56.doi: $10.1145 / 1978802.1978803$

Muchiri, Peter, Pintelon, Liliane, Gelders, Ludo and Martin, Harry.(2010). Development of maintenance function performance measurement framework and indicators. International Press.

Mugenda, O.M and Mugenda, A.G (2013) Research Methods, Quantitative \& Qualitative Approaches, Acts Press, Nairobi

Nachmias C. F. and Nachmias, D. (2006).Research Methods in the Social Sciences. $\left(5^{\text {th }}\right.$ edn) London, Hodder Arnold.

Naor, Michael, Susan M. Goldstein, Kevin W. Linderman, and Roger G. Schroeder (2013).The Role of Culture as a Driver of Quality Management and Performance: Infrastructure Versus Core Quality Practices. Decision Sciences, 671-702.

Olorunniwo, F. and Udo, G., (2012). The Impact of management and employees on cellular manufacturing implementation.International journal of production and Economics. 76, 27-38.

Oppenheim A. N. (2011), Questionnaire Design and Attitude Measurement. London. Heinemann Histogram

Orientation-Performance Relationship", Journal of Marketing, 64 (October 2010), 1-16.

Orodho, J.A. (2004). Techniques of Writing Research Proposals and Reports in EducationMasda Publishers 
Parzinger, M .J., and Nath, R. (2010). - A study of the relationships between total quality management implementation factors and software quality.Total Quality Management, $11,353-372$.

Prajogo, D. I. and Sohal, A. S. (2006).The relationship between organization strategy, total quality management (TQM), and organization performance-the mediating role of TQM.European Journal of Operational Research, 168, 35-50.

Prajogo, D.I., \& Brown, A. (2004). - The relationship between TQM practices and quality performance and the role of formal TQM programs: An Australian empirical study. Quality Management Journal, 11, 31-43.

Prescott, J. E. (2013). The evolution of competitive intelligence, in Hussey, D.E. (Ed.), International Review of Strategic Management, Wiley, Chichester. NY, pp. 1-22.

Psomas, E., Fotopoulos, C. \&Kafetzopoulos, D. (2010), Critical factors for effective implementation of ISO in SME service firms, Managing Quality management practices, 20(5), 440-57.

Radder, L. (1998). Stakeholders delight: the next step in TQM, The TQM Magazine, 10(4), 276-280.

RajkumarVenkatesan, Timothy Bohling, and Denise

Rodchua, S. (2006). Factors, measures, and problems of quality costs program implementation in the manufacturing environment. Journal of Industrials Technology, $1-6$.

rovement practices and the effect on manufacturing firm performance: evidence from Mexico and the USA, International Journal of Production Research, 39, pp. 43-63.

Samson, D. and Terziovski, M. (2009).The relationship between Total Quality Management practices and operational performance.Journal of Operations Management 17(4): 393-409.

Soltani, E. (2015). Top management: a threat or an opportunity to TQM? Total Quality Management, 16(4), 463-476.

Sousa, R., and Voss, C. A. (2011).Quality management re-visited: a reflective review and agenda for future research. Journal Operations Management,: 91-108.

Srikanthan, G., and Dalrymple, J. (2013).Developing alternative perspectives for quality in higher education, International Journal of Education Management, 17(3), 126-36.

Tam, M. (2011).Measuring quality and performance in higher education", Quality inHigher Education, 7(1), 47-54.

Tari JJ, Sabater V. (2006). Human aspects in a quality management context and their effects on performance.International Journal of Human Resource Management 17(3): 484503.

Terziovski, M. \& Power, D. (2017).Increasing ISO 9000 certification benefits: a continuous improvement approach. International Journal of Quality and Reliability Management, 2 (2), 141-163.

UNESCO (2013).Measuring Education Quality, Ministerial Round table on the Quality of Education, UNESCO Institute of Statistics, Paris,

Walker, F (2011). Stakeholder power.A winning plan for building stakeholder commitment and driving corporate growth, Perseus Publishing, the United States of America, P. 25-26.

Wernerfelt, B. (1984). A Resource- Based View of the Firm. Strategic Management Journal, $5(2), 171-180$

Wilson, D. D. and Collier, D. A. (2010).An empirical investigation of the Malcolm Baldrige national quality award causal model. Decision Sciences, 31 (2), pp. 361-383.

This is an open-access article published and distributed under the terms and conditions of the $(\mathrm{cc}) \mathrm{EY}$ Creative Commons Attribution 4.0 International License of United 
States unless otherwise stated. Access, citation and distribution of this article is allowed with full recognition of the authors and the source.

Authors seeking to publish with an International Peer Reviewed Journal should consider https://www.ijcab.org/ by writing to the Editor at editor@ijcab.org. The articles must be quality and meet originality test. 